\title{
The Preventive and Treatment Effect of Urtica dioica on Astrocyte Density in the CA1 and CA3 Subfields of Hippocampus in STZ Induced Diabetic Rats
}

\author{
Efecto Preventivo y del Tratamiento de Urtica dioica sobre la Densidad de Astrocitos en \\ los Subcampos CA1 y CA3 del Hipocampo en Ratas con Diabetes Inducida por STZ
}

\author{
Mohammad Jafar Golalipour"; Mehrdad Jahanshahi**; Soraya Ghafari**** \& Mohammad Afshar ${ }^{* * * * *}$
}

GOLALIPUR, M. J.; JAHANSHAHI, M.; GHAFARI, S. \& AFSHAR, M. The preventive and treatment effect of Urtica dioica on astrocyte density in the CA1 and CA3 subfields of hippocampus in STZ induced diabetic rats. Int. J. Morphol., 31(2):693-699, 2013.

SUMMARY: Several animal model studies have shown that Diabetes mellitus can affect on the activity of hippocampus astrocytes, but these studies reported controversial findings. This study was done to evaluate the preventive and treatment effect of $U$ rtica dioica ( $U$. dioica) on astrocytes density in the CA1 and CA3 subfields of hippocampus of streptozotocin (STZ) induced diabetic rats. Twenty-eight male albino Wistar rats were randomly allocated equally into control, diabetic, $U$. dioica treatment and $U$. dioica preventive groups. Hyperglycemia was induced by STZ $(80 \mathrm{mg} / \mathrm{kg} / \mathrm{BW})$. One week after injection of the streptozotocin, animals in treatment group were received hydroalcoholic extract of $\mathrm{U}$. dioica $(100 \mathrm{mg} / \mathrm{kg} / \mathrm{BW} /$ day $)$ for 4 weeks by intraperitoneally. In preventive group, diabetic rats were received $100 \mathrm{mg} / \mathrm{kg} / \mathrm{BW} /$ daily hydroalcoholic extract of $U$. dioica for 5 days before STZ injection. Then, animals were sacrificed and coronal sections were taken from the right dorsal hippocampus, stained with PTAH. The area densities of the astrocytes were measured. The number of astrocytes in CA1 of controls, diabetic treatment and preventive groups was 19.00 $\pm 5.5,17.14 \pm 6.4,21 \pm 8.1$ and $16.48 \pm 3.2$, respectively. The densities of astrocytes in CA3 of controls, diabetic, treatment and preventive groups were 25.45 $\pm 7.60,21.54 \pm 7.5,23.75 \pm 5.6$ and 19.89 \pm 3.8 , respectively. The density of astrocytes in diabetic rats reduced in comparison with controls $(\mathrm{P}<0.05)$. In CA1 and CA3, in spite of preventive administration, treatment of diabetic rats with $U$. dioica significantly increased the astrocytes. This study showed that treatment with $U$. dioica extract can help compensate for the CA1 and CA3 subfields of hippocampus astrocytes in diabetic rats.

KEY WORDS: Diabetes; Astrocyte; Urtica dioica; Hippocampus; CA1; CA3; Rat.

\section{INTRODUCTION}

Diabetes mellitus is one of the most common serious metabolic disorders (Gispen \& Biessels, 2000). Diabetes mellitus causes a variety of functional and structural alterations including hippocampal astrogliosis (Saravia et al., 2002), decreased hippocampal synaptic plasticity, neurotoxicity and changes in glutamate neurotransmission (Revsin et al., 2005) of the central nervous system.

Astrocytes as glial cells in the central nervous system are effective in Supporting of neurons, scar formation and maintenance of the blood-brain barrier (Afsari et al., 2008), vascular reactivity, regulation of extracellular glutamate levels, energy metabolism, and protection from reactive oxygen species (Dringen et al., 2000; Tsacopoulos \& Magistretti, 1996; Zonta et al., 2003).

Several animal model studies reported that Diabetes mellitus can affect on the activity of hippocampus astrocytes, but these studies reported controversial findings. some researches indicated that diabetes led to increasing of astrocytes (Saravia et al.; Baydas et al., 2003a, 2003b; Revsin et al.), but other studies have shown that diabetes mellitus reduced the number and activity of astrocytes (Coleman $e t$ al., 2004; Coleman et al., 2010).

\footnotetext{
* Professor, Gorgan Congenital Malformations Research Center, Department of Anatomical Sciences, Golestan University of Medical Sciences, Gorgan, Iran.

** Associate Professor, Neuroscience Research Centre, Department of Anatomical sciences, Golestan University of Medical Sciences, Gorgan, Iran.

**** Department of Anatomical Sciences, Golestan University of Medical Sciences, Gorgan, Iran.

***** Professor, Department of Anatomical sciences, Birjand University of medical Sciences, Birjand, Iran.
} 
Furthermore, several studies indicated that induction diabetes is associated with a reduction in GFAP-positive astrocytes in the spinal cord and death of hypothalamic astrocytes in poorly controlled diabetic rats (García-Cáceres et al., 2008; Afsari et al.).

In recent years, there has been renewed interest in plant medicine for the treatment of different diseases (Kameswara Rao et al., 2003; Ladeji et al., 2003). Isolated studies screened various plants having "folk medicine reputation" by biochemical test for this antidiabetogenic effect (Vats et al., 2002).

Urtica dioica L. Stinging nettle (Urticacea) is annual and perennial herb, distinguished with stinging hairs (Kavalali et al., 2003). Among the Urtica species, Urtica dioica (U. dioica) has already been known for a long time as medicinal plants in the world. The blood sugar lowering effect of $U$. dioica as a medicinal herb has been introduced in old script such as those written by Avicenna (Farzami et al., 2003). In addition, $U$. dioica is among several species listed for their use against diabetes in folk medicine in a large pharmacological screen of European species (Atta-UrRahman \& Zaman, 1989).

Since there is controversy about the effect of Diabetes mellitus on astrocytes alterations in the CA1 and CA3 subfields of hippocampus and lack of study regarding the effect of Urtica dioica on hippocampal astrocyte density, this study carried out to evaluate the preventive and treatment effect of $U$. dioica on astrocytes density in the CA1 and CA3 subfields of hippocampus of STZ induced diabetic rats.

\section{MATERIAL AND METHOD}

In this experimental study 28 adult male Wistar rats (weighing 250-300 g) were used. All animals were treated in agreement with the Helsinki Convention on the use of animals in research approved by the Institutional Review Board. The animals were kept in air-conditional animal room $\left(22 \pm 2^{\circ} \mathrm{C}\right)$ under a $12 \mathrm{~h}$ light/dark cycle.

Collection of Plant. Fresh leaves of $U$. dioica were collected from cultivated plant, from suburb of Gorgan, northern Iran (Golestan, Iran) in OCT 2005 and taxonomically identified by Department of Pharmacognosy, Mazandaran University of Medical Sciences. A voucher specimen (5-77-1) was deposited in the herbarium of Mazandaran University.

Preparation of extract of Urtica dioica. The dried and powered of $U$. dioica leaves $(400 \mathrm{~g})$ were percolated by
Ethanol (45\%) solvent. In briefly the dried leaf of $U$. dioica (by using hot air $35-40^{\circ} \mathrm{C}$ ) powdered by mechanical milling. Prelinering maceration during 5 hours was done and the product percolated and mixing during 48 hours. The extract was filtrated ( 0.8 Micron) and spray dried in a lab plant SD4 spray drier (lab plant ltd, England). Spectrophotometric assay was carried out to determine the concentration of phenolic and flavonid content of $U$. dioica leaves extract (Kraus \& Spiteller, 1991; Evans, 2002). Also antioxidant activity was measured by DPPH method.

Chemical. All chemical such as Streptozotocin (STZ) used were of analytical grade obtained from Merck and Sigma.

Experiment induction of diabetes. Streptozotocin was dissolved in saline immediately use and intraperitoneally injected. Diabetes was induced with a single intraperitoneally (IP) injection of Streptozotocin (STZ) $(80 \mathrm{mg} / \mathrm{kg})$ to overnight fast rats. Blood samples for glucose measurements were taken from the tail vein. Diabetes was confirmed by measuring the glucose concentration by using Glucometer method.

Experimental design. For this study four groups designed: Normal healthy control group (Group I), received Saline daily for 4 weeks. Diabetic group (Group II) received Saline daily for 4 weeks after STZ injection, Treatment group (Group III), diabetic rats that administered $100 \mathrm{mg} / \mathrm{kg} / \mathrm{BW} /$ daily hydroalcoholic extract of $U$. dioica (Gülçin et al., 2004; Kavalali et al.), for 4 weeks and preventive group, rats were received $100 \mathrm{mg} / \mathrm{kg} / \mathrm{BW} /$ daily hydroalcoholic extract of $\mathrm{U}$. dioica for five days and then diabetes induced by STZ. In the experiments, seven rats were used in each group.

Intraperitoneal glucose tolerance test (GTT). GTT was performed on $16 \mathrm{~h}$ fasted rats using $2 \mathrm{gram}$ glucose $/ \mathrm{kg}$ body weight. In all groups, blood was collected from the animals by tail snipping at $0,30,90$ and 120 minutes after glucose load. Also glucose test were performed after IP injection STZ in 1 and 5 weeks.

Histological and Morphometric studies. After the animals had been scarified, the brains were removed and fixed in buffered formaldehyde 10\% solution for histological analysis. Brains were cut coronally into $7 \mu \mathrm{m}$ slices. Approximately 10 slices obtained from each brain. Then they were processed and were stained with PTAH staining.

Then a photograph of each section was produced using an Olympus BX 51 microscope and a DP 12 digital camera under a magnification of 400 . An area of $20000 \mu \mathrm{m}^{2}$ was selected in the CA1 and CA3 subfields of hippocampus in all sections. To measure the area density of the astrocytes, 
the images were transferred to the computer. Using OLYSIA Autobioreport software, Olympus Co, the appropriate grids were superimposed on the pictures and the cells were counted manually.

Statistical analysis. Experimental data were evaluated using Spss v.11.5 and one way ANOVA and expressed as Mean \pm $\mathrm{SE} \mathrm{P}<0.05$ was considered significant.

\section{RESULTS}

Phytochemical analysis of extract showed the presence of phenolic and flavonids content, $22.8 \pm 2.7$ and $41.2 \pm 3.1 \mathrm{mg} / \mathrm{gram}$ dry extract, respectively. Antioxidant activity by DPPH method showed $25.5 \pm 2.2$ percent of scavenging activity.
The Glucose Tolerance Test (GTT) of the three groups at the beginning and the $5^{\text {th }} \mathrm{wk}$ of the study are showed in Fig. 1. As shown in Fig. 1, the GTT results of all rats were normal at the beginning of experiment. At the end of study control rats which have not received STZ showed a normal GTT. In contrast, the diabetic rats which have been undergone STZ-induced diabetes at the first day of study showed the most profound impairment GTT. Also result of GTT in treated group was similar to STZ-induced diabetes.

The density of astrocytes (per $20000 \mathrm{~mm}^{2}$ ) in CA1 and $\mathrm{CA} 3$ of hippocampus in control, diabetic Treatment and preventive groups are depicted on Fig. 2.

The number of astrocytes in CA1 area of controls, diabetic treatment and preventive groups was 19.00 \pm 5.5 , $17.14 \pm 6.4,21 \pm 8.1$ and $16.48 \pm 3.2$, respectively.

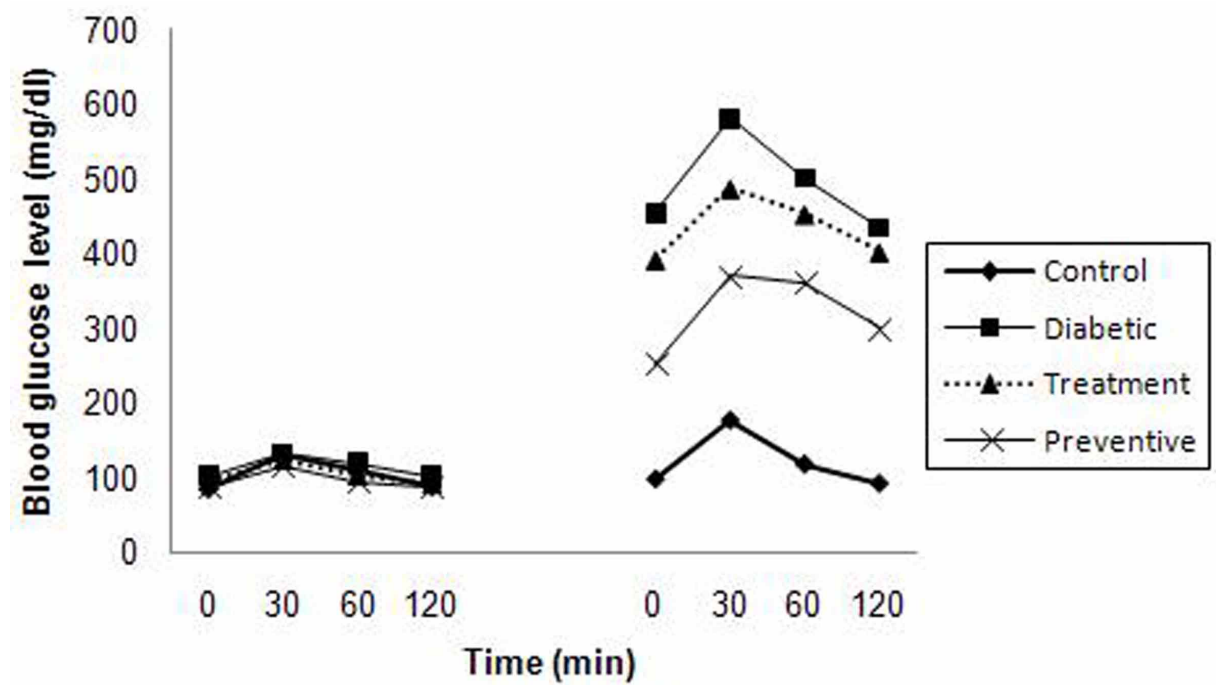

Fig. 1. The Glucose Tolerance Test (GTT) of the four groups at the beginning and the end of the study.

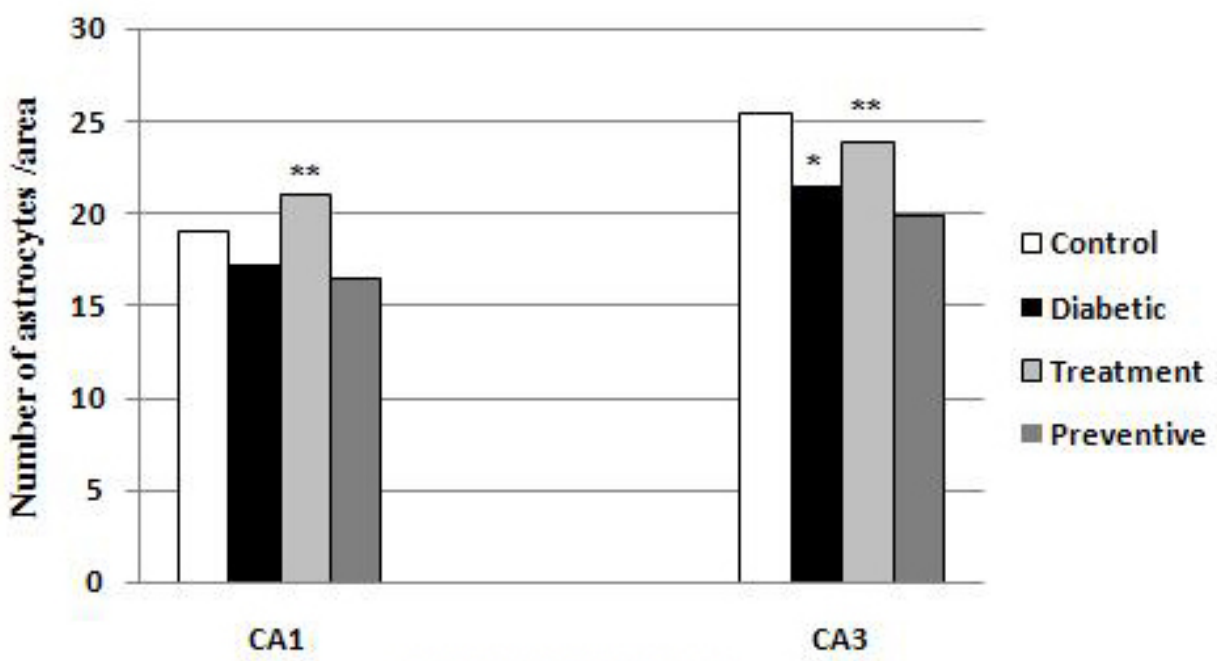

Fig. 2. Astrocytes number in CA 1 and CA3 in control, diabetic, treatment and preventive groups (* compared with control group, ** compared with diabetic group, $\mathrm{P}<0.05$ )

Hippocampal sectors 
In CA1, treatment of diabetic rats with $U$. dioica significantly increased the astrocytes as compared to diabetic group, but preventive administration of $U$. dioica does not alter the astrocytes density.

The densities of astrocytes in CA3 area of controls, diabetic, treatment and preventive groups were 25.45 \pm 7.60 , $21.54 \pm 7.5,23.75 \pm 5.6$ and $19.89 \pm 3.8$, respectively.

In CA3, the density of astrocytes in diabetic rats reduced as compared with controls $(\mathrm{P}<0.05)$. Treatment of diabetic rats with $U$. dioica significantly increased the astrocytes compared to diabetic group, but preventive administration of $U$. dioica had no effect on astrocytes density.

\section{DISCUSSION}

This study showed that astrocytes numbers were nonsignificantly reduced in CA1 and significantly reduced in CA3 in STZ induced diabetics rats. Our results is similar to previous studies (Coleman et al., 2004, 2010) and is contrast with others (Saravia et al.; Baydas et al., 2003a, 2003b; Revsin et al.).

Coleman et al. (2010) reported that diabetes reduce GFAP content in rats at 4 and 8 weeks of diabetes duration. Also, Lebed et al. (2008) indicated that GFAP cell count in CA1 and CA3 areas decrease in $3^{\text {rd }}$ day in STZ induced diabetic rats in comparison with controls.

Furthermore, reduction of astrocytes in spinal cord and hypothalamus were reported in didactic animals (GarcíaCáceres et al.; Afsari et al.). Reduction of astrocytes in diabetic animals can be due to astrocytes death by apoptosis (García-Cáceres et al.).

Apoptotic cell death occurs In diabetes mellitus in numerous tissues (Nishikawa \& Araki, 2007; Allen et al., 2005; Arroba et al., 2003, 2005, 2007; Lechuga-Sancho et al., 2006a, 2006b; Klein et al., 2004), with increase of glucose level (Romero et al., 2002; Anitha et al., 2006), decrease insulin or insulin-like growth factor signaling (Ishii, 1995) or an increase in cytokines such as TNFa (Chen \& Goeddel, 2002). Because, glial cells control the supply of glucose and its metabolites to neurons (Pellerin et al., 2007), they are the first line of defense against changes in glucose concentrations. Furthermore, when glucose availability is reduced, glycogen stored in astrocytes serves as a fuel source for neurons (Brown \& Ransom, 2007). Thus, it is possible that prolonged exposure to elevated glucose levels underlies the increase death of astrocytes.
High glucose levels directly induce death of different glial cell types (Xi et al., 2005; Delaney et al., 2001). However, increased TNFa (Arroba et al., 2005), decreased insulin (Arroba et al., 2007) or insulin growth factor (IGF)-I (Busiguina et al., 1996), could be involved in glial cell death.

The intracellular mechanism of the increase astrocytes death most likely involves nuclear translocation of AIF (apoptosis inducing factor) (García-Cáceres et al., 2008).

Nuclear translocation of AIF is involved in caspaseindependent cell death in response to a variety of signals, including oxidative stress, glutamate toxicity, and ischemia. Loss of mitochondrial membrane integrity results in the release of this factor, which can then be translocated to the nucleus where it induces DNA fragmentation and chromatin condensation (Krantic et al., 2007).

In other hand, several studies have reported that increase of number of astrocytes in diabetes mellitus (Saravia et al.; Baydas et al., 2003a, 2003b; Revsin et al.).

Baydas et al., (2003b) reported an increased GFAP immunostaining in the hippocampus of 6 weeks after induction of diabetes in rats in comparision with control animals.

Also, Saravia et al., study is founded that the number of GFAP cells significantly increase in SFZ-treated mice. Indeed, Saravia et al., reported that the number of GFAP astrocytes increased 3-fold in the hippocampal stratum radiatum of STZ-diabetic female mice compared with agematched, vehicle-treated non diabetic controls.

Furthermore, Muranyi et al., (2006), found that the number of GFAP-positive astrocytes significantly increase in the hippocampus of diabetic rats. Also he reported that the diameters of astrocytes body were found to be enlarged and the number and foot processes length of astrocytes were increased.

Astrocytosis is often related to neurodegenerative diseases and aging, in which neuronal dysfunction or damage can also accompanied (Goss et al., 1991; Magistretti \& Pellerin, 1999; Ridet et al., 1997).

The alterations of astrocytes number possibly due to oxidative stress (Baydas et al., 2003b) and free radical formation (Baydas et al., 2003a).

Studies have shown that hippocampus astrocytes of 
diabetic rats can changes due to melatonin and vitamin $\mathrm{E}$ (Baydas et al., 2003a,b). Vitamin E as an antioxidant agent and melatonin as a direct scavenger and indirect antioxidant can affect on astrocytes in diabetics model (Baydas et al., 2003a). In our study $U$. dioica leaves extract increased the astrocytes number in CA1 and CA3 of diabetic rats. Also, Renno et al., (2008),reported that diabetic rats treated with green tea showed a significant increase in the number GFAP-immunoreactive astrocytes in all the spinal cord gray areas as compared to waterdrinking diabetic rats.

In our previous studies, the treatment with $U$. dioica extract after induction of diabetes can help to restore diabetes-induced granule cell and astrocytes loss in the rat dentate gyrus (Fazeli et al., 2008; Jahanshahi et al., 2009)

In the present study, U. dioica extract $(100 \mathrm{mg} / \mathrm{kg} /$ BW daily for 4 weeks after induction of diabetes) increased the number of astrocyte in CA1 and CA3 of STZ-induced diabetic rats.

Neural protective properties of $U$. dioica extract in the $\mathrm{CA} 1$ and $\mathrm{CA} 3$ of diabetic rats hippocampus have been attributed to antioxidant and anti-apoptotic properties of $U$. dioica (Fazeli et al., 2010). It is founded that $U$. dioica contains phenolic compounds, particularly flavoniods (Mavi et al., 2004). Flavonoids generally have antioxidant potential (Hall \& Cuppett, 1997). Indeed, in our study, the preventive administration of $U$. dioica $(100 \mathrm{mg} / \mathrm{kg} /$
BW daily for 5 days before induction of diabetes could not alter the reduction of astrocytes in CA1 and CA3 of STZ-diabetic rats. Also, in our previous study, the preventive administration of $U$. dioica extract can not help to restore diabetes-induced astrocytes loss in the rat dentate gyrus (Golalipour et al., 2011).

Although, neural cell death protective properties of the extract in the CA1 and CA3 of diabetic mice hippocampus have been attributed to antioxidant and antiapoptotic properties of $U$. dioica, but lack of effect of $U$. dioica in this section of study may be due to low dosage and short duration of this plant before induction of diabetes in animals.

In conclusion, this study showed that astrocytes density of hippocampus reduce in STZ induced diabetic rats and $U$. dioica extract administration after induction of diabetes for 4 weeks can be a beneficial treatment for the regulation of astrocytes density in the in CA1 and CA3 of diabetic rats, but administration of $U$. dioica extract before induction of diabetes can not help compensate for astrocytes in hippocampus.

\section{ACKNOWLEDGEMENTS}

We thank the Deputy research of Golestan University of medical sciences and Dr. Vahid khori.

GOLALIPUR, M. J.; JAHANSHAHI, M.; GHAFARI, S. \& AFSHAR, M. Efecto preventivo y del tratamiento de Urtica dioica sobre la densidad de astrocitos en los subcampos CA1 y CA3 del hipocampo en ratas con diabetes inducida por STZ. Int. J. Morphol., 31(2):693-699, 2013.

RESUMEN: Varios estudios en modelos animales han mostrado que la diabetes mellitus puede afectar la actividad de los astrocitos del hipocampo, pero estos resultados son controvertidos. Este estudio se realizó para evaluar el efecto preventivo y de tratamiento de la Urtica dioica (U. dioica) en la densidad de los astrocitos en los subcampos CA1 y CA3 del hipocampo en ratas diabéticas inducidas por estreptozotocina (STZ). Veintiocho ratas Wistar albinas macho fueron asignadas al azar por igual en grupos control, diabético, con tratamiento $U$. dioica y preventivo con U.dioica. La hiperglucemia se indujo por STZ $(80 \mathrm{mg} / \mathrm{kg} / \mathrm{peso}$ corporal). Una semana después, los animales del grupo tratamiento recibieron el extracto hidroalcohólico de $U$. dioica (100 mg/kg/ peso corporal/día) durante 4 semanas vía intraperitoneal. El grupo preventivo, recibió $100 \mathrm{mg} / \mathrm{kg} /$ peso corporal/día de extracto hidroalcohólico $U$. dioica durante 5 días antes de la inyección de STZ. Los animales fueron sacrificados, se tomaron secciones coronales del hipocampo dorsal derecho y se tiñeron con PTAH. Fueron medidas las densidades de área de los astrocitos. El número de astrocitos en CA1 de los grupos de ratas control, diabéticas, con tratamiento de $U$. dioica y preventivo con $U$. dioica fue $19,00 \pm 5,5$, $17,14 \pm 6,4,21 \pm 8,1$ y 16,48 $\pm 3,2$, respectivamente. Las densidades de los astrocitos en CA3 de los grupos de ratas control, diabéticas, con tratamiento de $U$. dioica y preventivo con $U$. dioica fue $25,45 \pm 7,60,21,54 \pm 7,5,23,75 \pm 5,6$ y 19,89 $\pm 3,8$, respectivamente. La densidad de los astrocitos en las ratas diabéticas se redujo en comparación con los controles ( $\mathrm{P}<0,05)$. En CA1 y CA3, a pesar de la administración preventiva, sólo el tratamiento de ratas diabéticas con $U$. dioica aumentó significativamente los astrocitos. Este estudio mostró que el tratamiento con extracto de $U$. dioica puede ayudar a compensar los astrocitos de los subcampos CA1 y CA3 del hipocampo en ratas diabéticas.

PALABRAS CLAVE: Diabetes; Astrocitos; Urtica dioica; Hippocampo; CA1; CA3; Rata. 


\section{REFERENCES}

Afsari, Z. H.; Renno, W. M. \& Abd-El-Basset, E. Alteration of glial fibrillary acidic proteins immunoreactivity in astrocytes of the spinal cord diabetic rats. Anat. Rec. (Hoboken), 291(4):390-9, 2008.

Allen, D. A.; Yaqoob, M. M. \& Harwood, S. M. Mechanisms of high glucoseinduced apoptosis and its relationship to diabetic complications. J. Nutr. Biochem., 16(12):705-13, 2005.

Arroba, A. I.; Frago, L. M.; Argente, J. \& Chowen, J. A. Activation of caspase 8 in the pituitaries of streptozotocin-induced diabetic rats: implication in increased apoptosis of lactotrophs. Endocrinology, 146(10):4417-24, 2005.

Arroba, A. I.; Frago, L. M.; Paneda, C.; Argente, J. \& Chowen, J. A. The number of lactotrophs is reduced in the anterior pituitary of streptozotocin-induced diabetic rats. Diabetologia, 465(5):634-63, 2003.

Arroba, A. I.; Lechuga-Sancho, A. M.; Frago, L. M.; Argente, J. \& Chowen, J. A. Cell specific expression of X-linked inhibitor of apoptosis in the anterior pituitary of streptozotocin-induced diabetic rats. J. Endocrinol., 192(1):215-27, 2007.

Anitha, M.; Gondha, C.; Sutliff, R.; Parsadanian, A.; Mwangi, S.; Sitaraman, S. V. \& Srinivasan, S. GDNF rescues hyperglycemiainduced diabetic enteric neuropathythrough activation of the PI3K/ Akt pathway. J. Clin. Invest., 116(2):344-56, 2006.

Baydas, G.; Nedzvetskii, V. S.; Tuzcu, M.; Yasar, A. \& Kirichenko, S. $\mathrm{V}$. Increase of glial fibrillary acidic protein and S-100B in hippocampus and cortex of diabetic rats: effects of vitamin E. Eur. J. Pharmacol., 462(1-3):67-71, 2003a.

Baydas, G.; Reiter, R. J.; Yasar, A.; Tuzcu, M.; Akdemir, I. \& Nedzvetskii, V. S. Melatonin reduces glial reactivity in the hippocampus, cortex, and cerebellum of streptozotocin-induced diabetic rats. Free Radic. Biol. Med., 35(7):797-804, 2003b.

Brown, A. M. \& Ransom, B. R. Astrocyte glycogen and brain energy metabolism. Glia, 55(12):1263-71, 2007.

Busiguina, S.; Chowen, J. A.; Argente. J. \& Torres-Aleman, I. Specific alterations of the insulin-like growth factor I system in the cerebellum of diabetic rats. Endocrinology, 137(11):4980-7, 1996.

Coleman, E. S.; Dennis, J. C.; Braden, T. D.; Judd, R. L. \& Posner, P. Insulin treatment prevents diabetes-induced alterations in astrocyte glutamate uptake and GFAP content in rats at 4 and 8 weeks of diabetes duration. Brain Res., 1306:134-41, 2010.

Coleman, E. S.; Judd, R.; Hoe, L.; Dennis, J. \& Posner, P. Effects of diabetes on astrocyte GFAP and glutamate transporters in the CNS. Glia, 48(2):166-78, 2004.

Chen, G. \& Goeddel, D. V. TNF-R1 signaling: a beautiful pathway. Science, 296(5573):1634-5, 2002.
Delaney, C. L.; Russell, J. W.; Cheng, H. L. \& Feldman, E. L. Insulinlike growth factor-I and over-expression of Bcl-xL prevent glucosemediated apoptosis in Schwann cells. J. Neuropathol. Exp. Neurol., 60(2):147-60, 2001.

Dringen, R.; Gutterer, J. M. \& Hirrlinger, J. Glutathione metabolism in the brain. Metabolic interactions between astrocytes and neurons in the defense against reactive oxygen species. Eur. J. Biochem., 267(16):4912-6, 2000.

Evans, W. C. Trease and Evans Pharmacognosy. W. B. Saunders. Edinburgh, Churchill-Livingstone, 2002. pp.211-214,

Farzami, B.; Ahmadvand, D.; Vardasbi, S.; Majin, F.J. \& Khaghani, Sh. Induction of insulin secretion by a component of Urtica dioica leave extract in perifused islets of Langerhans and its in vivo effects in normal and streptozotocin diabetic rats. Ethnopharmacol., 89(1):47-53, 2003.

Fazeli ,S. A.; Gharravi, A. M.; Ghafari, S.; Jahanshahi, M. \& Golalipour, M. J. The granule cell density of the dentate gyrus following administration of Urtica dioica extract to young diabetic rats. Folia Morphol. (Warsz), 67(3):196-204, 2008.

Fazeli, S. A.; Gharravi, A. M.; Ghafari, S.; Jahanshahi, M. \& Golalipour, M. J. Effects of Urtica dioica extract on CA3 hippocampal pyramidal cell loss in young diabetic rats. Neural Regen. Res., 59(12):901-5, 2010.

García-Cáceres, C.; Lechuga-Sancho, A.; Argente, J.; Frago, L. M. \& Chowen, J. A. Death of hypothalamic astrocytes in poorly controlled diabetic rats is associated with nuclear translocation of apoptosis inducing factor. J. Neuroendocrinol., 20(12):1348-60, 2008.

Gispen, W. H. \& Biessels, G. J. Cognition and synaptic plasticity in diabetes mellitus. Trends Neurosci., 23(11):542-9, 2000.

Golalipur, M. J.; Ghafari, S.; Latimfimoghadam, M. H. \& Kaboli, S. Alteration of dentate gyrus astrocytes in diabetic rats: Protective role of Urtica dioica. Int. J. Morphol., 29(4):1307-12, 2011.

Goss, J. R.; Finch, C. E. \& Morgan, D. G. Age-related changes in glial fibrillary acidic protein mRNA in the mouse brain. Neurobiol. Aging, 12(2):165-70, 1991.

Gülçin, I.; Küfrevioglu, O. I.; Oktay, M. \& Büyükokuroglu, M. E. Antioxidant, antimicrobial,antiulcer and analgesic activities of nettle (Urtica dioica L.). Ethnopharmacol., 90(2-3):205-15, 2004.

Hall, C. A. \& Cuppett, S. L. Structure-Activities of Natural Antioxidants in: Aruoma OI, Cuppett SL(ed) Antioxidant methodology in vivo and in vitro concepts. Champaign, AOCS Press, 1997. pp.141-72.

Ishii, D. N. Implication of insulin-like growth factors in the pathogenesis of diabetic neuropathy. Brain Res. Rev., 20(1):47-67,1995.

Jahanshahi, M.; Golalipour, M. J. \& Afshar, M. The effect of Urtica dioica extract on thenumber of astrocytes in the dentate gyrus of diabetic rats. Folia Morphol. (Warsz), 68(2):93-7, 2009. 
Kameswara Rao, B.; Renuka Sudarshan, P.; Rajasekhar, M. D.; Nagaraju, N. \& Appa Rao, C. H. Antidiabetic activity of Terminalia pallida fruit in alloxan induced diabetic rats. J. Ethnopharmacol., 85(1):169-72, 2003

Kavalali, G.; Tuncel, H.; Goksel, S. \& Hatemi, H. H. Hypoglycemic activity of Urtica pilulifera in streptozotocin-diabetic rats. Ethnopharmacol., 84(2-3):241-5, 2003.

Klein, J. P.; Hains, B. C.; Craner, M. J.; Black, J. A. \& Waxman, S. G. Apoptosis of vasopressinergic hypothalamic neurons in chronic diabetes mellitus. Neurobiol. Dis., 15(2):221-8, 2004.

Kraus, R. \& Spiteller, G. Ceramides from Urtica dioica roots. Eur. J. Org. Chem., 2:125-8, 1991.

Krantic, S.; Mechawar, N.; Reix, S. \& Quirion, R. Apoptosis-inducing factor: a matter of neuron life and death. Prog. Neurobiol., 81(3):179-96, 2007.

Ladeji, O.; Omekarah, I. \& Solomon, M. Hypoglycemic properties of aqueous bark extract of Ceiba pentandra in streptozotocin-induced diabetic rats. J. Ethnopharmacol., 84(2-3):139-42, 2003.

Lebed, Y. V.; Orlovsky, M. A.; Nikonenko, A. G.; Ushakova, G. A. \& Skibo, G. G. Early reaction of astroglial cells in rat hippocampus to streptozotocin-induced diabetes. Neurosci. Lett., 444(2):181-5, 2008.

Lechuga-Sancho, A. M.; Arroba, A. I.; Frago, L. M.; García-Cáceres, C.; Delgado Rubín de Célix, A.; Argente, J.; et al. Reduction in the number of astrocytes and their projections is associated with increased synaptic protein density in the hypothalamus of poorly controlled diabetic rats. Endocrinology, 147(11):5314-24, 2006a.

Lechuga-Sancho, A. M.; Arroba, A. I.; Frago, L. M.; Paneda, C.; GarcíaCáceres, C.; Delgado Rubín de Célix, A.; et al. Activation of the intrinsic cell death pathway, increased apoptosis and modulation of astrocytes in the cerebellum of diabetic rats. Neurobiol. Dis., 23(2):290-9, 2006b.

Magistretti, P. \& Pellerin, L. Astrocytes couple synaptic activity to glucose utilization in the brain. News Physiol. Sci., 14:177-82, 1999.

Mavi, A.; Terzi, Z.; Ozgen, U.; Yildirim, A. \& Coskun, M. Antioxidant properties of some medicinal plants: Prangos ferulacea (Apiaceae), Sedum sempervivoides (Crassulaceae), Malva neglecta (Malvaceae), Cruciata taurica (Rubiaceae), Rosa pimpinellifolia (Rosaceae), Galium verum subsp. verum (Rubiaceae), Urtica dioica (Urticaceae). Biol. Pharm. Bull., 27(5):702-5, 2004.

Muranyi, M.; Ding, C.; He, Q.; Lin, Y. \& Li, P. A. Streptozotocin-induced diabetes causes astrocyte death after ischemia and reperfusion injury. Diabetes, 55(2):349-55, 2006.

Nishikawa, T. \& Araki, E. Impact of mitochondrial ROS production in the pathogenesis of diabetes mellitus and its complications. Antioxid. Redox Signal, 9(2):343-53, 2007.

Pellerin, L.; Bouzier-Sore, A. K.; Aubert, A.; Serres, S.; Merle, M.; Costalat, R. \& Magistretti, P. J. Activity-dependent regulation of energy metabolism by astrocytes: an update. Glia, 55(12):1251$62,2007$.

Atta-Ur-Rahman \& Zaman, K. Medicinal plants with hypoglycemic activity. J. Ethnopharmacol., 26(1):1-55, 1989.

Renno, W. M.; Alkhalaf, M.; Afsari, Z.; Abd-El-Basset, E. \& Mousa, A. Consumption of green tea alters glial fibriliary acidic protein immunoreactivity in the spinal cord astrocytes of STZ-diabetic rats. Nutr. Neurosci., 11(1):32-40, 2008.

Revsin, Y.; Saravia, F.; Roig, P.; Lima, A.; de Kloet, E. R.; HomoDelarche, F.; et al. Neuronal and astroglial alterations in the hippocampus of a mouse model for type 1 diabetes. Brain Res., 1038(1):22-31, 2005.

Ridet, J. L.; Malhotra, S. K.; Privat, A. \& Gage, F. H. Reactive astrocytes:cellular and molecular cues to biological function. Trends Neurosci., 20(12):570-7, 1997.

Romero, G.; Liu, W. H.; Asnaghi, V.; Kern, T. S. \& Lorenzi, M. Activation of nuclear factor-kappaB induced by diabetes and high glucose regulates a proapoptotic program in retinal pericytes. Diabetes, 51(7):2241-48, 2002.

Saravia, F. E.; Revsin, Y.; Gonzalez, D. M. C.; Gonzalez, S.; Roig, P.; Lima, A.; et al. Increased astrocyte reactivity in the hippocampus of murine models of type I diabetes: the nonobese diabetic (NOD) and streptozotocin treated mice. Brain Res., 957(2):345-53, 2002.

Tsacopoulos, M. \& Magistretti, P. J. Metabolic coupling between glia and neurons. J. Neurosci., 16(3):877-85, 1996.

Vats, V.; Grover, J. K. \& Rathi, S. S. Evaluation of antihyperglycemic effect of Trigonella foenum-graecum Linn., Ocimum sanctum Linn. and Pterocarpus marsupium Linn. in normal and alloxanised diabetic rats. J. Ethnopharmacol., 79(1):95-100, 2002.

Xi, X.; Gao, L.; Atala, D. A.; Smith, D. G.; Codispoti, M. C.; Gong, B.; et al. Chronically elevated glucose-induced apoptosis is mediated by inactivation of Akt in cultured Muller cells. Biochem. Biophys. Res. Commun., 326(3):548-53, 2005.

Zonta, M.; Angulo, M. C.; Gobbo, S.; Rosengarten, B.; Hossman, K. A.; Pozzan, T.; et al. Neuron to astrocyte signaling is central to the dynamic control of brain microcirculation. Nat. Neurosci., 6(1):4350, 2003.

Correspondence to:

Dr. Mohammad Jafar Golalipour

Gorgan Congenital Malformations Research center,

Department of Anatomical sciences,

Golestan University of medical Sciences,

P.O. Box: 49175-1141

Gorgan

IRAN

Email: mjgolalipour@yahoo.com

Received: 27-06-2012

Accepted: 24-09-2012 